\title{
The Theory, Practice and Current Trends in Federalism
}

\author{
Obi, Emeka Anthony* Ph.D \\ Associate Professor of Public Administration, Chukwuemeka Odumegwu University Igbariam Campus, \\ Anambra State Nigeria
}

*Corresponding Author: Obi, Emeka Anthony, Associate Professor of Public Administration, Chukwuemeka Odumegwu University Igbariam Campus, Anambra State Nigeria

\begin{abstract}
Federalism as a system of government seem to have been more generally accepted as the best system of government for managing multi-ethnic states in order to allow each of the constituent units enough elbow room for autonomous development Though the system has been in operation for centuries now, there is a large measure of disagreement among scholars on the theory of federalism This disagreement has led use of terms as quasi federalism to describe some countries whose brand of federalism seem different from the American type, despite the fact that they are apparently practicing a federal system. This paper explicates on the theory of federalism extensively and the present trends in both its theory and practice. It relies on the theory of intergovernmental relations as an explanatory variable. Its data is mainly from secondary sources. It concludes that since different countries that adopt the federal principle, are different in many respects there are bound to be noticeable differences in these different systems.
\end{abstract}

Keywords: Federalism, Intergovernmental Relations, Constituent Units and Diversity

\section{INTRODUCTION}

Federalism as a political arrangement has faced a serious crisis of conceptualization. This is because as Elazar(1977) says "there has been several varieties of political arrangements to which the term has properly been applied". Riker (1975), advanced this argument further by pointing out that :

An initial difficulty in discussion of federalism is that the meaning of the word has been thoroughly confused by dramatic changes in the institutions to which it refers. Hence, a word that originally referred to institutions with emphasis on self government has come to connote also domination by a gigantic impersonal concentration of force".

Based on the above therefore, it is not surprising that there are varying definitions of federalism, which actually seem to contradict each other. It is this seeming confusion that made Dare (1979) to conclude that "the present study of federalism is in a theoretical jungle" This paper is devoted to a theoretical explication of the concept with a view to rescuing it from this seeming jungle, and then situating it within the ambit of current trends in the evolution of federalism..

\section{THEORETICAL FRAMEWORK}

There are quite some theories and models that seek to explain the practice of intergovernmental relations. One of the most popular of these is Dell Wrights models of intergovernmental relations which this study adopts. These models are contained in his 1988 book with the title "Understanding Intergovernmental Relations" He identifies three models of intergovernmental relations namely: coordinate authority model, inclusive authority model and overlapping authority model.

The coordinate authority model depicts one of independence between the national and state governments, in such a way that each of them has a high level of autonomy over its functions. In this model, the level of autonomy enjoyed by local authorities is only minimal. According to Benjamin (2004), for a long time, this model of IGR came closest to approximating the patterns of governance in the United States. This explains a situation wheare national-state contacts were relatively modest and the power of the two levels were exercised in a rather separate, independent and autonomous manner. 
The overlapping authority model depicts a high level of interdependent relationships among the three levels of government. Benjamin (2004) states that this "involves three intersecting and overlapping circles'". In cases wheare the circles do not overlap, it is proper to infer an arena of autonomous action by the respective jurisdictions (p.63). Wright (1988), believes that the authority pattern in this model is based mainly on bargaining between the national and state governments.

The third and last model is the inclusive authority model. This is clearly a situation of hierarchical and dependent relationships among the national, state and local government authorities. More explicitly, Benjamin emphasizes that: 'This pattern of concentric circles is so named because it implies no arenas of state or local autonomy outside the sphere of control by the national government. Similarly, no local autonomy exists outside the sphere of complete state control" (p. 63). Ikelegbe (2004) clearly explains this model as one in which:

Federal penetration, dominance, and subordination of other constituent governments is fairly total and comprehensive, such that the latter become so dependent and weak as to be mere appendages or even extensions. Intergovernmental relations becomes extensively centralized, integrated and guitarist as the federal balance is so heavily tilted towards the center as to make federalism even in its most pragmatic proposition scurry. In some states, authoritarian and particularly military and military-based dictatorships have so transformed federal practice that an inclusive authority model has emerged (p.131).

The coordinate authority model depicted a clear separation between national and state/local relationships and the distinct boundaries separating the levels of government. The inclusive authority model, by contrast, presented a system in which IGRs were based on essentially a hierarchical set of relationships and emphasized the predominant role of the national level.

But it is the overlapping model- that was essentially a new way of depicting intergovernmental relationships. The Venn diagram that Wright used to describe intergovernmental relationships in this model presented IGR as a set of overlaps among national, state and local units simultaneously. It also presented the relationships as one in which the autonomy and discretion in a single jurisdiction are constrained and hence, emphasized the role of bargaining between actors in that model (p.3).

There is no doubt that no single model of intergovernmental relations can be used to explain federalism in all states as there are variants of each of these three models in different states and even in the same states at different points in time.

\section{THE THEORY OF FEDERALISM}

Since the first notable attempt at a definition of federalism was done by K.C. Wheare, most other scholars on the subject matter have used his definition as a point of departure. According to Wheare (1953) "by the federal principle 1 mean the method of dividing powers so that general and regional governments are each, within a sphere, coordinate and independent"(p.10). He further listed the principles of federalism as;

- The division of powers among levels of government;

- Written constitution showing this division; and

- Coordinate supremacy of the two levels of government with regards to their respective functions

More extensively he asserts that:

First of all since federal government involves a division of functions and since the states forming the federation are anxious that they should not surrender more powers than they know, it is essential for a federal government that there be a written constitution embodying the division of powers, and binding all governmental authorities throughout the federation. From it, all state and federal authorities derive their powers and any actions they perform contrary to it are invalid. In the second place, if the division of powers is to be guaranteed, and if the constitution embodying the division is to be binding upon federal and state governments alike, it follows that the power of amending that part of the constitution which embodies the division of powers must not be conferred either upon the federal government acting alone or upon the state governments acting alone, it is preferable, though essential, to federalism that the power should be exercised by the federal and state authorities acting in cooperation... 
Thirdly... in case of dispute between federal and state governments as to the extent of the powers allocated to them under the constitution, somebody other than the federal and state governments must be authorized to adjudicate upon those disputes. Finally, if the governmental authorities in a federation are to be really coordinate with each other, in actual practice as well as in law, it is essential that there should be available to each of them, under its own unfettered control, financial resources-sufficient for the performance of the functions assigned to it under the constitution. It is no good allotting functions to the federal or to state authorities and devising legal safeguards so that each should be limited strictly to the performance of its respective functions, unless at the same time adequate provision has been made so that each authority can afford to do its job without appealing to the others for financial assistance. For if state authorities, for example, find that the services allotted to them are too expensive for them to perform, and if they call upon the federal authority for grants and subsidies to assist them, they are no longer coordinate with the federal government but subordinate to it. Financial subordination makes an end of federalism in fact, no matter how carefully the legal forms may be preserved. It follows therefore that both state and federal authorities in a federation must be given the power in the constitution each to have access to and to control, its own sufficient financial resources. Each must have a power to tax and to borrow for the financing of its own services by itself (pp28-31).

It is clear from a common understanding of federalism that Wheare is quite right in his postulations, however his conceptualization has been seen as been too legalistic and inflexible (Birch 1968). It is criticized for been a description of American federalism which in any case. Wheare saw as the archetype of federalism. He seemed to have forgotten that even the American federalism was a reflection of the socio-political conditions and history of America and has equally witnessed some changes since the Philadelphia Convention of 1787 wheare the constitution was adopted. In any case, the American Patriots that converged in Philadelphia stated that "they gathered for the purpose of rendering the articles of confederation adequate to the exigencies of government and the preservation of the Union".

It is therefore apparent from the above that since the American federalism was fashioned, bearing in mind the 'exigencies of government', it cannot be the ideal as K.C. Wheare felt, since every society ought to fashion its own system to make it "adequate to the exigencies of government". These exigencies we know, must take into consideration, the peculiarities, history and eccentricities of the local conditions of the country fashioning out the constitution.

However, for the purposes of classification, an irreducible minimum standard ought to be set so that any society that goes beyond that would not be classified as having a federal system.

In his own criticism of Wheare, Jinadu (1979) asserts that,

It seems to me that the crucial defect of Wheare's and other similar formulations of federalism is not that it is excessively legalistic. It's major weakness, rather, is that it stresses formal institutional requirements-explicit. constitutional delimitation of powers, bi-cameral legislature, independent electoral systems for both levels of government, multi-party but preferably a two party system, a supreme court- as if they are defining characteristics of federalism or perhaps logically built into the meaning of federalism(p.16).

Perhaps what may have provoked, the attacks on Wheare was his seeming arrogance, rigidity and selfelevated infallibility when he said:

I have put forward uncompromisingly a criterion of federal government- the delimited and coordinate division of governmental functions and I have implied that to the extent to which any system of government does not conform to this criterion, it has no claim to call itself federal (p.34).

He therefore went ahead to label countries that are apparently federal but do not fully conform to his criterion as 'quasi federal' to distinguish them from 'true federalism', Wheare's legalistic or juridical approach, which has been criticised for being too rigid or rather placing much emphasis on the legal dimensions of federalism while ignoring other socio-political factors has given rise to many other conceptualizations of federalism.

In order to make up for the short comings of Wheares' presentation, Livingston (1956) took care of sociological and political factors in his own formulation. He thus states that: 
The essential nature of federalism is to be sought for, not in the shading of legal and constitutional terminology', but in the forces-economic, social, political, cultural that have made the outward forms of federalism necessary. The essence of federalism lies not in the constitutional or institutional structure but in the society itself. Federal government is a device by which the federal qualities of the society are articulated and protected (pp1-2).

In distinguishing a federal society from a non-federal one and the role which diversities play in a federation he argues that:

These diversities may be distributed among the members of a society in such a fashion that certain attitudes are found in particular territorial areas, or they may be scattered widely throughout the whole of the society. If they are grouped territorially, i.e. Geographically, then the result may be a society that is federal. If they are not grouped territorially, then the society cannot be said to be federal............But in the former case only can this take the form of federalism or federal government. In the latter case it becomes functionalism, pluralism or some form of corporativism (p.23).

The utility of Livingston's conceptualization lies on his belief that federalism is a reflection of the inherent diversities in a society. It is a system fashioned to hold different nations together in a state, while still allowing each of them a degree of autonomy in certain areas. It gives room for unity in diversity. To borrow Ramphal's (1979) phrase "It is a methodology of limited union directed to the production of limited unity"(p.xiv).

Despite Livingston's efforts in freeing federalism from Wheare's rigidity, he has not escaped criticism over his own formulation. His formulation is seen as so broad, that virtually all countries can with little effort be classified as federal states, Others have also criticised him for almost ignoring the 'juristic aspect' of Wheare's conceptualization. Thus Riker (1964) argues that:

Even in common usage federalism is a juristic concept of sorts, and that fact is retained in our definition by emphasizing the existence of two kinds of governments and their separate ability to make some decisions independently of each other.

To Riker (1964), federalism, "is a political organization in which the activities of government are divided between regional governments and a central government in such a way that each kind of government has some kind of activities on which it makes final contributions"(p.101).

Jackson and Jackson (1994), believe that this definition:

Implies that each level of government has more-or-less complete authority over some specific spheres of activity, while on a few matters there may be a degree of concurrent jurisdiction. There is certainly no single, ideal way in which this authority is divided. What is important is that each level has a degree of autonomy. In the federal form, the various levels of government obtain their respective powers from the country's constitution, not from each other. Citizens owe some loyalty to more than one level of government, and both levels may act directly on the citizens (p.240).

In trying to analyse Riker's contribution to the theory of federalism, Dare (1979) states that he (Riker) viewed federalism from a static perspective, as a bargain struck by the component units. According to Riker the two prerequisites for the bargain are;

- The desire by the leaders to expand their territorial control, usually either to meet an external military or diplomatic aggression and aggrandizement; and

- The presence of some external military-diplomatic threat or opportunity.

These two conditions which according to him are responsible for a federal union may be centralized or conversely peripheralized. In a centralized federal system, there is a "tendency for the rulers of the federation to overawe the rulers of the constituent governments". (Riker 1964) Wheareas in a peripheralized federation, the rulers of the subordinate governments have greater influence over the affairs of the whole society than the rulers of the federation. However, Jackson and Jackson (1994), argue that for a variety of reasons ranging from the requirements of national security, the welfare state and in general, the growing complexity of society, are all factors conducive to the centralization of power at the national level. They also point out the fact, that there are however, states in which the 
various regional sub-units retain significant powers, wheareas there are countries wheare it is possible to discern pendulum swings along the continuum over a period of decades. They conclude by arguing that "although centralized federalism is the more common form today, there is nothing intrinsically superior or inferior about the arrangement"(p.241).

Dare (1979), concludes by saying that "Riker's insight that political parties may be the source of harmony or disharmony in federal system's can be classified as the introduction of behavioural aspect into what was hitherto legal studies".

Suffice it to say that, whether one agrees with Wheare or not, the most fundamental thing about federalism is that there must be a constitutional division of powers between levels of government. The manner of cooperation between or among these levels may differ from one state to another or even in the same state at different points in time to reflect political changes in that state. It is therefore, to take care of both the juridical and socio-political factors that Fredrich (1966) posited that;

Federalism seems the most suitable term by which to designate the process of federalizing a political community, that is to say, the process by which a number of separate political organisations, be they states or any kind of association enter into arrangements for working out solutions, adopting joint policies and making decisions on joint problems or reversely the process through which a hitherto unitary political community as it becomes differentiated into a number or separate and distinct political communities achieve a new organization in which the differentiated communities now separately organized become capable of working out separately and on their own, those problems they no longer have in common.

It is indeed quite ironical that while trying to avoid the pitfalls of other theorists, Fredrich fell into a bigger pit. His conceptualization was so broad and magnanimous as to even include international groups, or associations. However, as if realising the inherent danger in such a broad classification of a concept, he stipulated the defining characteristics of federal systems as;

- An Assembly of representatives of component communities which after instituting the league usually by way of a charter or treaty, amends it when necessary;

- An executive establishment of some sort to carry out the decisions of the assembly; and

- An arbitral or judicial body interpreting the treaty in it's bearing upon the relations between members of the league and between them and the league as a whole, thus seeking to eliminate the recourse to arms.

Finally, he defines federalism as:

A union of group selves, united by one or more common objectives but retaining their distinctive group being for other purposes. Federalism is, on the inter-group level, what association is on the interpersonal level. It unites without destroying the selves that are uniting, and it is meant to strengthen them in their mutual relations

Dare (1979) sees Friedrich's method as a round-about way to approach a theory by first describing as federal, any form of cooperation organized on special basis, and then trying to make the definition conditional upon the presence of the above named three factors. By so doing he made the three features as requisites of federalism.

In trying to look at the concept under question, Ramphal (1979) explained that:

...federalism, in it's broadest conception, is a process of unifying power within the cluster of states and decentralizing power within the unified state. At the one end, therefore, we may have what is no more than a confederation or a linking together by treaty of sovereign states for particular purposes-little more than a diplomatic arrangement in which internal sovereignty is preserved and external sovereignty limited to only a very minor degree, an arrangement which emphasizes the plurality not the unity, of member states of the confederation. And, at the other end of the spectrum, the process of federalism will commence the movement away from absolute and undiluted national sovereignty beginning with almost imperceptible shading off into decentralization-devolution, to be more fashionable-within a unitary political structure (p.xiv).

He goes further to say that if he were to delineate the system at the centre of the federal spectrum, he would Portray it as a pragmatic method of organising government so that sovereignty and political 
power are combined within a single nation of several territorial units but are so distributed between national and unit governments that each within it's own sphere, is substantially independent of the others.

He further explained the emphasis on substantially in the above, because "particularly as between the centre and the regions, that independence is never absolute and perhaps never can or should be"(p.xiv).He reasoned that, "judged by the standards of classical federalism, it is the criterion of coordinate status that largely determines the quality of the nations federalism" p.(xiv).

The apparent problem we have with building a generally acceptable theory of federalism is simply as a result of the fact that "the practical necessities of a miscellany of national circumstances, not the symmetry of academic reasoning have given it its content and it's form" (Ramphal 1979). Scholars are therefore torn between giving a descriptive analysis of what they have observed in some federations and elevating into a 'theory' and adopting a normative approach meant to set the standards of what federalism should be.

All in all, none of the attempts to build a theory of federalism could be said to be a futile exercise. Dare (1979) puts it succinctly when he said that :

On close examination, it can be observed that no fundamental disagreements exist among the writers in their divergent approaches to the topic. Each approach is a narrow perspective of the broad theme, and non by itself explains the totality of the federal concept or its dynamics.

We should therefore not be bothered about the seemingly anarchy of 'theories' that seek to explain the concept of federalism. Perhaps we may conclude by saying that we all know what a federal system is, but we still lack a generally acceptable language, to explain what we know. Perhaps, with a little more effort we may arrive at a consensus soon. Perhaps.

Beyond the issue of theories, one other important dimension to the discuss on federalism is the reasons why different countries adopt a federal system, or what could equally be considered the advantages of federalism. To start with, it is quite apt to trace the origin of federalism as a system of government before looking for justifications of its use in different countries. According to Jackson and Jackson (1994):

The history of the concept of federalism has been traced back to the fusion of ancient Israelite tribes. In North America, its first occurrence has been ascribed to the Five Nations of the Iroquois Indians. Its modern meaning, however, is best dated to the eighteenth century. During that period, the United States Constitution provided a system of government that has been emulated ever since (p.241).

In terms of its adoption by the United States, Turner, Switzer, and Redden (1996), argue that delegates at the 1787 Philadelphia Constitutional Convention confronted with the difficult task of determining what the role of the national government should be, what powers should it have?, and then what about the powers of the states?. As expected, they had different answers to these questions, but many of them were also interested in limiting the powers of any new government and to guarantee the rights of the people, thus a unitary government was out of the question. They wanted a strong national government that would meet the many challenges facing the new nation, while bearing in mind the fact that the earlier confederate form of government had ended in disillusionment. At the same time, they also needed assurance that the powers of the states would not be swept away.

They subsequently discovered the magic wand, as:

The solution to their dilemma was found in the idea of federalism, a system of government in which powers are shared between a national government and the various state governments. Under a federal form of government, the central government would have enough power to stabilize and unify the country and to act in such matters of widespread national concern as defence, foreign relations and general welfare. At the same time, the states would act in matters of more local concern (p.514).

Federalism also fits well with the delegates' desire to restrict governmental powers. Each level would have a specific realm of authority and power; its own public officials, government agencies, and duly enacted laws; and legal authority within its own geographic boundaries. Both levels of government would exercise their authority at the same time and over the same people, yet neither could act outside 
the powers granted to it by the Constitution. By creating a federal system, the delegates ensured that the government would have the strength to endure and the flexibility to succeed (pp.514-515).

In tracing the origin of federalism, Ramphal (1979), did argue that:

Federal solutions to the problems of governmental organisation had been pursued over the ages long before Philadelphia: in the City States of ancient Greece, in the Italian cities of the Middle Ages, in an almost continuos development of the Swiss Confederation from the thirteenth century. Through all these processes of experimentation federalism as a method of organising government has been hammered out over many centuries by peoples the world over with creativity and constant innovation and always on the anvil of political reality(p.xiv).

Going further, he states that:

Almost a century before Philadelphia, federalism was already influencing experiments in governmental organisations in the Western hemisphere- in the scattered islands of the Caribbean. Starting with a consultative body comprising representatives of the various island legislatures, a General Assembly of the Leeward islands came into being in the 1680's and soon developed the character of a federal council legislating on matters of common concern. Between 1690 and 1705, for example, it passed some 55 separate Acts including an organic instrument- an Act of 1705 entitled in language essentially federalist " an Act to settle General Councils and General for the Caribbean islands in Americans and to secure to each particular island their peculiar laws and customs"(p.xiv).

In terms of the advantages of federalism, Rosenbloom and Kravchuk (2002), have identified some of them as:

Such nations are likely to be powerful economically and militarily. They will be more likely to mobilize effectively large scale human effort to pursue their vision of "the good life" and the just society. They are likely to have a greater human and physical resource base than smaller nations. Their large scale may also enable them to develop more vigorous economies within their territories. There is likely to be less internal strife among the units of a single nation than there would be if that nation were divided into separate countries having full sovereignty and autonomy(p.103).

On their own, Jackson and Jackson (1994), believe that the two most often-cited motivations for "federal unions are the desire for military security and the desire for economic or political expansion"(p.243). Finally, they add that the dual essence of American federalism was the idea of distribution of government power on an area basis, and the philosophy that unity and diversity can co-exist.

On the other hand, Rosenbloom and Kravchuck posit that despite its noted advantages, federalism can also have some drawbacks which mainly concern representation and keeping the parts together. While Jackson and Jackson believe that when considering the perceived gains, sub-units must also consider the drawbacks in terms of the fact that they must give up some privileges and powers to the central government. In doing this they must also bear in mind the fact many apparently stable federal states have endured stresses and strain, and on occasion, even failure. Relying on Watts (1977), they identify four common conditions of failure: regional divergences of political demands, weak communications, a diminution of the original impetus for union and external influences.

Heywood (2002), who sees federalism as referring to legal and political structures that distribute power territorially within a state, posits that there are at least four factors that account for the adoption of federalism by different countries. The first of these is historical similarities. In virtually all cases, federations have been formed by the coming together of some nationalities that still wished to preserve their separate identities and to some measure, their autonomy. The second factor is the existence of an external threat or a desire to play a remarkable role in the international system. By merging with other political communities in a federation, they become bigger, stronger, visible and more capable of containing external threats and playing more noticeable role in world affairs.

The third factor is geographical size. Since large states tend to be more culturally diverse and possess more strong regional tradition, which creates greater pressures for decentralisation and the dispersal of power, federalism comes in handy as the best system. Finally, is the factor of cultural and ethnic 
heterogeneity. No doubt federalism's emphasis on limited unity or rather unity in diversity recommends it as the best system for heterogenous countries that are interested in maintaining peace among their diverse peoples.

In terms of the evaluation of federalism, he see its main advantages as first, giving the regional and local interests a constitutionally guaranteed political voice. Secondly, in diffusing government power, it creates a network of checks and balances that helps to protect individual liberty. Finally federalism has provided an institutional mechanism through which fractured societies have maintained unity and coherence.

In his own analysis, Makarenko (2008),has outlined the potential benefits and detriments of federalism.

The first benefit of federalism is that it acts as an additional check on governmental power. In unitary systems, power is usually concentrated and centrlized in a single level of government, wheareas in federal systems, power is dispersed amongst different levels of government. This makes it difficult for one set of political elites to dominate, control the power and direction of government. Even the different levels also act as a check on each other in the operation of government.

Federalism helps to protect local or regional interests to a considerable extent. Since most modern states are very large and have diverse populations, some regional groups may have different political needs from those of other regions. In this instance, federalism can prevent geographically-basd minorities from being oppressed by allowing them some level of political autonomy through the creation of states/regions/provinces.

Federalism makes it easier to manage and administer large geographical areas. Having only one level of government administering a large territory is usually very cumbersome especially in the past when telecommunication and transportation were not well developed. The existence of lower levels of government who take care of local issues reduce the burden on the central government.

On the other hand, though federalism can act as a check on government power, it can lead to paralysis and impede governments ability to deal with difficult national issues. This arises from the fact that the division of jurisdictions inherent in federalism may not allow the federal government from implementing national programmes in areas outside its jurisdiction.

As federalism is known to protect local and regional interests, it is also known to encourage divisions within a country, as the emphasis on unity in diversity may inflame divisive and fissiparous tendencies.

He however concludes by insisting that:

It is important to note, however, that whether a particular federal state exhibits these possible benefits and detriments depends in large parts on how divides power between levels of government. A highly centralized federal state, for example may not act as a check on government power or protect regional interests, due to the fact that most powers (or at least the most important ones) are given to the central government (para.15).

In their own analysis, Simeon and Murray cited in (Schwella nd). have identified the following as the advantages of federalism:

Federalism serves democracy by increasing opportunities for participation, bringing governments closer to the people, and introducing checks and balances that may minimize opportunities for majority tyranny.

Federalism also serves developmental goals by allowing policies and programmes to be tailored to the specific needs and preferences of particular regions, and may increase transparency and accountability; again by bringing officialdom closer to the people they serve.

Federalism promotes inter-group harmony by giving each constituent group a political space of their own in which they are able to express their own values, identities and interests without fear of domination or veto by a central government controlled by an ethnic majority(pp.86-87).

On the other hand, they have also identified some counter-arguements on whether federalism is the most suitable system for developing countries. These arguments are:

With respect to democracy, there is the danger that local interests may frustrate the will of a democratic majority. 
There are also conflicting views as to whether decentralised decision-making is actually less prone to problems such as elite domination and corruption.

Federalism in many ways is designed to create competing centres of power in weak fragile states. This may generate instability as rival elite exploit this for their sectional benefit.

With respect to economic and social development policy and delivery, fragmented authority may impair the ability to mobilize the financial and human resources to address massive developmental challenges successfully.

Intergovernmental beggar-thy- neighbour policies may frustrate development, and decentralization may make redistribution of wealth, or sharing, more difficult.

Finally, in respect of diversity, federalism can potentially entrench, institutionalize, perpetuate and exacerbate the very challenges it is designed to manage. It may provide nationalist ethnic elites with a platform from which to promote secession or ethnic cleansing(p.87).

It is instructive to note that they cautioned that how the above plays out depends on the specific design of federal or decentralized institutions, and even more depends on the particular circumstances of individual countries, which include:

- The number and character of diverse groups;

- Their colonial legacies;

- The distribution of wealth and resources across the territory;

- The skills and capacities available to governments at local, provincial and national levels; and

- The design and effectiveness of other elements in the institutional structure, such as legislatures, electoral systems, the judiciary and Bills of rights (p.88).

\section{EVOlVing PATterns OF FEDERALISM}

Since the introduction of federalism in America in 1787, the system has evolved through three main patterns: Dual federalism, Cooperative federalism, and the New federalism. The Australian Government Issue Papers 1 2014- A Federation For Our Future says that:

The terms 'layer cake federalism' and 'marble cake federalism' are sometimes used to describe two different types of federalism. In layer cake federalism (also called 'coordinate federalism'), each level of government has discrete areas of responsibility separated by 'clean lines' with no overlap. However, the complexity of modern society and a modern economy and the effects of globalisation mean that all federations have significant, albeit different, levels of overlapping responsibility. The term 'marble cake federalism describes the situation wheare many responsibilities are shared by the levels of government, and wheare governments cooperate to achieve common objectives. 'Collaborative federalism' and cooperative federalism' also describe this type of federalism (para,6)

\subsection{Dual Federalism}

This model of federalism fits well into K.C.Wheare's definition of federalism as "a method of dividing powers so that general and regional governments are each within a sphere, coordinate and independent". This is because this model emphasizes the superiority of each level of government in its area of responsibility. It means according to Hague and Harrop (2001), that "the national and state governments in a federation retained separate spheres of action. Each level independently performed tasks allocated to it by the constitution"(p.206).The model emphasizes the fact that neither level is dominant and neither level should intervene in the affairs of the other(Rosenbloom and Kravchuk 2002).It was the system that was operated from the beginning of American federalism in 1787, when the states were so much concerned about protecting their autonomy. Dual federalism is also referred to as "layer-cake federalism, and in terms of intergovernmental relations, it is seen as the "coordinate authority model", which is marked by state-centered type of federalism.

\subsection{Cooperative Federalism}

The introduction of the New Deal as part of measures to contain the Great Depression of the 1930'smarked the end of dual federalism and the introduction of cooperative federalism. In this era, the American federal government provided large doses of federal finances to states to fund job creation, social welfare and infrastructure development. It was a period characterised by serious cooperation between the state and federal government and a high level of interdependency between 
them. The period in question lasted from roughly 1933 to about 1964. Cooperative federalism to Hague and Harrop (2001), based on the principles of cooperation and interdependence between levels, wheare by national and state governments are expected to collaborate in pursuit of the interests of the whole, a philosophy which apparently is at odds with the contractual foundations of dual federalism. An authority on federalism, Daniel Elazar justifies the movement from dual federalism to cooperative federalism by arguing that:

Whether cooperative federalism was intended by the fathers of the union or not, it was quickly demonstrated to be necessary. Governments operating in the same territory, serving the same people, generally sharing the same goals and faced with the same demands could not maintain a posture of dual federalism(1965,p.11).

Cooperative federalism is also referred to as "marble cake federalism", while in intergovernmental relations, it is called the overlapping model. Hague and Harrop (2001), believe this model offers a more realistic account of how federal government proceeds in practice. This is because in this system, the central government offers overall leadership but leaves implementation to lower levels- a division rather than a separation of tasks.

\subsection{Creative Federalism}

This was a system that introduced by President Lyndon Johnson through the Great Society programmes. These programmes created so much categorical grants designed to promote health care, crime reduction, poverty reduction etc. What made it 'creative' was the use of federal grants- in-aid given directly to the cities and counties to execute federal programmes, thereby bypassing the states.

\subsection{New Federalism}

This system which emerged under President Roland Reagan was aimed at returning responsibility for some the federal programmes back to the states. This was influenced by Reagan's view that "the federal government has taken functions it was never intended to perform and which it does not perform well. There should be a planned, orderly transfer of such functions to states and localities"(cited in Turner, Switzer and Redden (1996). The Reagan government consolidated most of the categorical programmes into nine block grant while also reducing transfers to states and localities. However, they were given more freedom in spending these block grants.

\section{FEATURES OF FEDERALISM}

We must emphasize here that there are no generally agreed features of federalism. It is the absence of these generally agreed features that has led to the argument of whether there is true federalism and the issue of some labelling countries they feel do not possess certain features they consider important as quasi federalism. May be the attempt by K.C. Wheare to list what he considered the essential features of federalism based on the American experience and at the same time insisting that countries that do not have these features have no business calling themselves federal, marked the beginning of this problem. These have already been discussed earlier on in this paper.

Determining the features of federalism therefore has been reduced to identifying those certain features that seem common to most federal systems following the tradition of Wheare, but while recognizing that no two countries are the same, and no system can be replicated without modifications elsewheare. Heywood (2002) has identified the following features:

- Two relatively autonomous levels of government;

- Written constitution;

- Constitutional arbiter; and

- Linking institutions.

\section{CONCLUSION}

This chapter had tried to elucidate on the theory of federalism from the premise that there is still some notable disagreement among scholars on what federalism actually means. Though there doesn't seem to be much doubt about the distinction between unitary and federal systems, the problem seem to be the insistence by some scholars that all federal systems must look like the American system being the archetype of federalism. To this group, once a system has substantial differences from the American 
one, it is not true federalism. This is a mistaken notion, because just as no two countries are the same in all respects, there is no way two countries can operate the same system in exactly the same way. Countries are expected to adapt any system they adopt to suit their peculiar needs and circumstances. It is therefore wrong to talk about true federalism, instead we can talk about American federalism, Canadian federalism, Australian federalism, Nigerian federalism and so on. This is because all these countries have variations in their adaptation of federalism based on their history, peculiarities, and eccentricities of local conditions.

\section{REFERENCES}

[1] Australian Government Issue Paper 1 (2014). A federalism for our future. https://www.cefa.org.au/ccf/ federalism-changing-australia.

[2] Benjamin, S.O. (2004).Federal state and state-state relations in Nigeria: A case study of Lagos state. In F.O. Egwaikhide, E.R. Aiyede, S.O. Benjamin, H. D. Dlakwa, \& A.Ikelegbe (Eds).Intergovernmental relations. Ibadan : PEFS

[3] Dare, L.O. (1979).Perspective on federalism. In A.B.Akinyemi, P. D. Cole \& W. Ofonagoro (eds). Readings on Federalism: Lagos N.I.I.A

[4] Elazar, D. J. (1977).The ends of federalism: Notes towards a theory of federal political arrangements. In M. Frankel (Ed). Partnership in federalism. Bern: Peter Hang

[5] Etzioni, A. (1962). A paradigm for the study of political clarification. World Politics Vol. 15 No. 1

[6] Friedrich, C. (1963). Federalism: National and international. Oxford University Press

[7] Jinadu A.L (1979). A note on the theory of federalism. In Akinyemi et al (Eds.).Readings on federalism. Lagos: NIIA.

[8] Livington, W.S. (1952). A note on the feature of federalism. Political Science Quarterly Vol. LXII No 2 March.

[9] Obikeze, S.O , Obi E.A., \&Iwuala, V.C. (2016). Government \& politics of Nigeria. The struggle for power in an African state. Onitsha: Bookpoint Ltd.

[10] Makarenko, J. (2008). Federalism in Canada: Basic framework and operation. https://www. mapleleafweb.com/ features/federalism-canada-basic-framework-and-operation.html

[11] Obi, E..A.(2004).Issues in the theoretical foundations of federalism. In E.A. Obi \& S.O Obikeze.(Eds.) Federalism and national integration in Nigeria. Onitsha:Bookpoint Ltd.

[12] Oyovbaire,S.E.(1985). Federalism in Nigeria.London: Macmillan Publishers.

[13] Rosenbloom, D.H.\& Kravchuk, R.S.(2002).Public administration. Understanding management, politics and law in the public sector. Boston: McGraw-Hill.

[14] Ramphal, S.S.(1979). Keynote Address at the International Conference on Federalism held in Lagos Nigeria in May 1976. In B. Akinyemi et al (eds). Readings on federalism. Lagos : NIIA

[15] Riker, W. (1962). Federalism: Origin, operation, significance Boston, Little Brown

[16] Wheare K.C. (1953). Federal government .(4th ed.). Oxford University Press.

[17] Hague, R \& Harrop, M. (2001). Comparative government and politics. An introduction ( $5^{\text {th }}$ ed). NewYork : Palgrave.

[18] Heywood, A. (2002). Politics (2nd ed.) New York: Palgrave Macmillan.

[19] Ikelegbe, A. (2004). Intergovernmental relations, government and development in Nigeria. In

[20] Jackson, R. \&Jackson., D. (1994).Politics in Canada. Culture, institutions, behaviour and public policy (3rd.ed.). Scarborough, Ontario: Prentice Hall.

[21] Ezeani, E.O. (2018).Contentious issues in Nigerian federalism and the clamour for restructuring of the polity. Kalu Ezera Annual Lecture by the Nigerian Political Science Association,(NPSA). South East Zone held at University of Nigeria Nsukka Oct 30th.

[22] Turner, M. J., Switzer, K. \& Redden, C. (1996).American government. Principles and practices. Westville Ohio: Glencoe/McGraw-Hill.

Citation: Obi, Emeka Anthony. "The Theory, Practice and Current Trends in Federalism ". International Journal of Research in Tourism and Hospitality (IJRTH), vol 5, no. 1, 2019, pp. 30-40. doi: http://dx.doi.org/10.20431/2455-0043.0501005.

Copyright: (1) 2019 Authors. This is an open-access article distributed under the terms of the Creative Commons Attribution License, which permits unrestricted use, distribution, and reproduction in any medium, provided the original author and source are credited. 